\title{
RIVERBANK EROSION DISPLACEES IN BANGLADESH: NEED FOR INSTITUTIONAL RESPONSE AND POLICY INTERVENTION
}

MD Fakrul Islam, Ph.D, and A.N.M. Bazlur Rashid, Ph.D.

1. Professor, Department of Social works, University of Rajshahi, Bangladesh

2. University of Rajshahi, Bangladesh

ABSTRACT: Environmental refugees are one of the most burning issues at this time throughout the world. Bangladesh, a riverine country, is suffering from acquit riverbank erosion which compels millions of her population to be displaced from their place of origin. As such, 283 locations, 85 towns and growth centers, along with 2400 kilometers of riverbank line in Bangladesh are vulnerable to erosion. The major rivers e.g., the Padma, the Jamuna, and the Meghna, erode several thousand hectares of floodplain making thousands of people landless and homeless every year. Along with the floodplain, Bangladesh loses several kilometers of roads, railways, and flood-control embankments annually. No other disaster is as disastrous as riverbank erosion and 'Internally Displaced Populations' (IDP) face many unavoidable problems at different stages of displacement. Displacement marginalized them in respect of livelihood patterns and psycho-physical troubles. Such forty million homeless people in Bangladesh are compelled to lead a floating life. Riverbank erosion plays a major role in socio-environmental changes. The displaced people of riverbank erosion experience substantial socio-economic impoverishment and marginalization as a consequence of involuntary displacement from their original residence. Findings of a social survey carried out in 2008 on the erosion-hit displaced people in Chapai Nawabganj and Rajshahi districts are discussed in this paper. Newly settled people along with the native inhabitants have been interviewed to reveal the problems associated with making rearrangements for the displaced people. Besides these problems of displacement, adaptation strategies and relationships with the local people, their socioeconomic losses, sufferings, perception of natural disaster and psycho-physical problems, environmental ruins etc. have been revealed in this paper. There are no specific policies to rehabilitate the erosion-hit people. Thus, it is time to formulate policies to address prevention of riverbank erosion as well as to rehabilitate the river-erosion refugees.

\subsection{INTRODUCTION}

Bangladesh is a land of rivers. More than 700 rivers, with their tributaries and distributaries have criss-crossed the country forming a network of river system. It has about 2,400 kilometers of bank line and along with the bankline there are 283 locations, 85 towns and growth centers are vulnerable to erosion ${ }^{1}$. The Padma (The Ganges), the Jamuna and the Meghna, major rivers of Bangladesh, erode several thousand hectares of floodplain, making thousands of people landless and homeless every year.

In recent years, throughout the world, victims of environmental disasters are growing in number than the victims of war or other (man-made) forceful migration. Victims of such political violence receive satisfactory media coverage along with different types of assistance from various national and international agencies. But the uprooted migrants- caused by environmental disasters- fail to attract such level of local or international attention which tends them to be more vulnerable. According to the United Nations University (UNU), victims of political violence receive a lot of assistance from governments and international organizations in forms of financial grants,

${ }^{1}$ Sustainable Embankment Maintenance through Promoting Settlers' Rights

http://www.coastbd.org Dated: 23 June 2007 
food, tools, shelter, schools and clinics, but "environmental refugees" have not such access to receive aid. ${ }^{2}$ An empirical study conducted among the riverbank erosion displacees of Rajshahi and Chapai Nawabganj, two districts of Bangladesh, by writers in 2009. The respondents were displaced due to erosion of the Padma and the Mahananda, two rivers of the said two districts.

\subsection{EXTENT OF BANK-EROSION AND DISPLACEMENT}

Rivers constantly alter their course, changing shape and depth, trying to find a balance between the sediment transport capacity of the water and the sediment supply. This process, called riverine erosion or riverbank erosion, is usually seen as the wearing away of riverbanks and riverbeds over a long period of time. Riverbank erosion is often initiated by failure of a riverbank causing high sediment loads or heavy rainfall. This generates high volume and velocity run-off which will concentrate in the lower drainages within the river's catchments area. When the stress applied by these river flows exceeds the resistance of the riverbank material, erosion will occur. As the sediment load increases, fast-flowing rivers will erode their banks downstream. Eventually, the river becomes overloaded or velocity is reduced, leading to the deposition of sediment to further downstream or in dams and reservoirs. The deposition may eventually lead to the river developing a new channel. While all rivers change in the long-term, short-term rates of change vary significantly. In less stable braided channel reaches, erosion and deposition of material are a constant issue. In more stable meandering channels, episodes of erosion may only occur occasionally. The erosion rate depends on the sediment supply and amount of run-off reaching the river. These variables are affected by many things including earthquakes, floods, climatic changes, loss of bank vegetation, urbanization, and the construction of civil works in the waterway. There are varieties of natural and human-induced factors that influence the erosion process. For example, bankline orientation and exposure to prevailing winds and waves all influence erosion rates. Bankline composition influences erosion rates as well. For example, riverbank composed of sand and silt are easily eroded whereas banklines primarily consisting of boulders or large rocks are more resistant to erosion. Other factors may include: bankline type, geomorphology of the riverbank, structure types along the bankline, density of development, amount of encroachment into the high hazard zone, proximity to erosion inducing bankline structures, nature of the riverbank topography, elevation of riverbank dunes and bluffs, and bankline exposure to wind and waves.

Riverbank erosion has many consequences including the loss of land and any development on that land. It can cause increased sedimentation of harbors and river deltas. It can hinder channel navigation - affect marine transportation source. This char dynamics is related to the morphologic behavior of rivers and in particular to the bank erosion processes and the prevailing trends of widening and narrowing of rivers ${ }^{3}$. Other problems include reduction in water quality due to high sediment loads, loss of native aquatic habitats, damage to public utilities (roads, bridges and dams) and maintenance costs associated with trying to prevent or control erosion sites.

Bangladesh is located at the confluence of the three mighty river systems of the world-the Padma, the Brahmaputra and the Meghna- renders her one of the most vulnerable places to natural disasters. Flood and riverbank erosion are the main disasters initiated from the river. During the last three decades (1970-2000), the Padma and the Jamuna have consumed 180,000 hectares of land. In 2008, bank erosion of the Padma, forced about 200,000 people to be homeless ${ }^{4}$, along with 1630 acres of mainly agricultural land, 370 settlement areas, 3930 meters of road, 9 educational institutes, 5 hats and bazaars and 1 union parishad was eroded.

Satellite image studied on the Ganges-Brahmaputra-Mehgna rivers showed that about 106,300 hectares of land was lost between 1982 to 1992, when the amount of accreted land was only 19,300 hectares. So, the net annual

\footnotetext{
${ }^{2} \mathrm{http}$ ://environment.about.com/od/globalwarming/a/envirorefugees.htm

${ }^{3}$ Environment and GIS Support Project for Water Sector Planning, Riverine Chars in Bangladesh (Dhaka: The University Press Limited, 2000), p. 20.

${ }^{4}$ The daily Jugantor, 21.06.2008.
} 
loss was 8,700 hectares during this period. It has estimated that about one million people become directly or indirectly affected by riverbank erosion every year. The ISPAN studied during 1981 and 1993, using satellite images and population data suggested that a total of 728,439 people were displaced from their original homestead by riverbank erosion. This also estimated that the annual number of displaced persons to be 63,722 . Estimation shows that, 50 percent of the total homeless people are victims of riverbank erosion and they cannot rebuild their home due to poverty and scarcity of resources. Four million of such homeless people in Bangladesh are compelled to lead a floating life ${ }^{5}$.

Report of the Climate Institute published in 1995, says that a growing number of people are displaced as a result of environmental problems such as drought, soil erosion, desertification and deforestation. ${ }^{6}$ It has further estimated that about 3.3 million people in Indonesia and 7.1 million in India are at risk from flooding and inundation by 2070 . It also expressed awareness of large-scale displacement in Bangladesh caused by sea level rising and coastal or riverbank erosion.

Scholars are also predicting that 50 million people worldwide will be displaced by 2010 because of coastal/riverbank erosion, rising sea levels, desertification, dried up aquifers, weather-induced flooding and other serious environmental changes. The number of refugees worldwide grew from 9.9 million in 2007 to 11.4 million in 2008, according to a report by the United Nations High Commissioner for Refugees (UNHCR), which identified climate change as one of the leading causes of the global rise in refugees.

Geography and Environmental Science Department of the Jahangirnagar University presented a chart of the losses of riverbank erosion from 1996 to 2000 , which is as follows: ${ }^{7}$

\begin{tabular}{|l|l|l|l|}
\hline Year & Financial Loss & Affected areas & $\begin{array}{l}\text { Affected } \\
\text { population }\end{array}$ \\
\hline 1996 & $5809 \mathrm{~m}$ & 71680.4 Acres & 10103635 \\
\hline 1997 & $33012 \mathrm{~m}$ & 7756 Acres & 173090 \\
\hline 1998 & $2201 \mathrm{~m}$ & 41519 Acres & 321000 \\
\hline 1999 & $10535 \mathrm{~m}$ & 227755 Acres & 899275 \\
\hline 2000 & $3286 \mathrm{~m}$ & 219310 Acres & 415870 \\
\hline
\end{tabular}

From the above chart it is clear that the financial loss is not negligible, extent of riverbank erosion is high in the land-scarce country and displacement of people is needed to give maximum attention. To protect the lives and resources from erosion, there should be effective policy and programs of the government as well as nongovernmental organizations.

\subsection{PROBLEMS OF THE DISPLACEES}

Riverbank erosion displacees face few unavoidable problems in different times of displacement, i.e. before displacement, during shifting household materials and family members and after displacement at their new settlement area. Displacee households were living in a settled area from generation to generation. Due to riverbank erosion, they were forced to migrate from their place of origin to other places, mostly unknown to them. Displacement due to riverbank erosion marginalized them in respect of livelihood patterns and psycho-physical troubles.

\subsubsection{Losses for Displacement}

Riverbank erosion is such an environmental catastrophe which cannot be compared to other environmental disasters. In every disaster, other than earthquake, people lose their household structure at best but due to

\footnotetext{
${ }^{5}$. Coast Trust, www.coastbd.org

${ }^{6} \mathrm{http} / /$ www.climate.org/publications/environmental-refugees.html

${ }^{7}$ ibid.
} 
riverbank erosion people lose their land and become homeless. Only the difference is, death counts less in number. Riverbank erosion displacees' losses are unbound. There are few losses, which can never be converted to money. Besides the loss of land, they lose other things too. Being homeless, they become assetless too. People of the study area have lost their agricultural and homestead land in one hand and on the other hand they became rootless, ousted from their community, broken down their family ties and social bondage. The effect was enormous and the loss was quite impossible to regain.

\subsubsection{Loss of Land and Changes in Land Holding Capacity}

Riverbank erosion aggravates land of the riparian inhabitants. It was found that, all of the respondents of study area had lost their land, either totally or partially. They were displaced from their original homestead, which was an unwilling displacement. Impact of unwilling displacement is always negative, either economically or socially. Land is fundamental for civilization, to build home and establish family followed by a society. From the study it was found that loss of land, as well as displacement, was the only reason for their present sufferings and other problems. They expressed that they followed their own strategy and system to mitigate needs and problems. But due to displacement and settling in a new area, things were out of their reach. Searching for homestead land turned into priority and a few of them managed to become landowner. A number of respondents were found, determined not to make settlement in their present living place.

\subsubsection{Changes in Economic Activities and Loss of Income}

Any kind of displacement has direct impact on regular sources of income and income generating activities of the displacee households. This change may be positive or negative but some sort of change is found in every situation faced by the affected people. If it was caused by a sudden forceful event which consequently causes unwilling displacement, the effect was counted severe. Loss of income compelled them to live a sub-standard life and they could not continue their way of living even parallel to the way before displacement. Displacement induced by natural disaster was different from other types of displacement. If it was due to any authority, the displacees were compensated and resettled by the authority. But displacement due to natural disaster did not make any room for the affected population rather they were victimized by several ill-motivated stakeholders. They faced difficulties to find new sources of income in new settlement area. Riverbank erosion displacees took shelter in distant places or migrated to urban areas. The landless and jobless heads of the households under financial duress $^{8}$ often deserted their families. Left alone, women of those households had to struggle hard to maintain their family.

From the collected data, it was found that about 75 percent respondents counted loss of income due to riverbank erosion induced displacement. On the other hand, the frequency of displacement had significant impact on income. It was found that number displacement played negative impact on total monthly income of the affected households. The households which were displaced more times became more affected in terms of total monthly income. Once upon a time, during pre-displacement period, some of them provided jobs to their comparatively poor neighbors, in post-displacement time; bank erosion leveled them with others, who were living side by side at the present settlement area. These two groups were struggling for same goal. In the new settlements, they were searching for shelter and security, at the same time, they were eager to get a job to feed the dependant members of their family and buy daily needs.

\footnotetext{
${ }^{8}$ Nizamuddin, op.cit., p. 3.
} 


\subsubsection{Loss of House-structure}

In rural areas of Bangladesh, generally the houses are not constructed by modern architectural design or with modern building materials. Most of the houses are designed by the household-head himself or other local laborer. Unburned brick, straw, chatai and bamboo-chatai are used extensively for most of the houses in rural areas of Bangladesh. A few are constructed by brick, or concrete materials. The roof is generally constructed by tin, straw, tiles, and a few are with concrete materials. It was found that all the respondents had lost their houses due to riverbank erosion. Some of them managed to shift their movable house materials to the present location. When erosion took place and came towards their houses, they all together dismantled their houses themselves pursuing to shift household materials. But all of them did not get enough time to take house materials. They told during the FDG and interview that most of them sold their houses to vendors, who employed a number of laborers and took-off the materials.

\subsubsection{Loss of Crop}

With the loss of land, a significant number of the riparian inhabitants lost their standing crops also. Rich landowners suffered more loss of crops than relatively smaller landowners. Crop was their main source of income and when they failed to harvest their crop in time, they suffered from shortage of money following unavoidable misery. They had to wait for next harvest, which was far away from present time. In the mean time, to meet daily expenditure they had nothing to do but to borrow money, in most of the cases, by lending their land to money-owners, locally known as mahajon. At the time of river bank erosion, if there were standing crop in the field, sometimes farmers harvest those knowing that they will not get food grain but may be used for fuel or animal food. Loss of crop had direct impact on local as well as national production of crop. The study region was generally a surplus region in food production. But due to riverbank erosion, a large number of displacees faced food scarcity. Many indigenous crops were being extinct due to loss of agricultural land and changing occupation of the farmers. Dependency on others for food was increased in number. Once upon a time, they were well set for rice and other cereals. But due to loss of land and displacement from their original homestead their dependency for food and cereals on others was remarkable.

\subsubsection{Loss of Security}

Security was another hazard faced by the displacees in the new settlement area. In the new settled area, some of them managed only a room for living but other homestead materials remained open under the sky. They identified five sectors of insecurity in the early days in new area. Those were: valuable goods might be stolen, household goods might be lost, women and girls might be harassed, attack of animal or bite by snake, and infants or children might be missed. For this reason, they followed some indigenous strategies and measures to minimize the insecurity fear. They dug a hole inside the room, and kept valuable goods such as, cash, ornaments etc. inside the hole in a polythene bag. Some of them, put valuables in a pot on reticulate bags ${ }^{9}$. They tied up and stacked other household materials. Male members kept watching at night by turns. Most of them had no enough money to light hurricanes at night. So, they managed to use torch-light at night. Watching at night helped them to feel secured from danger. Especially, they felt secured from thief or ill-motivated people. Women and younger girls slept inside the room to be more secured. Other members including males lied down on floor in front of the

${ }^{9}$ Reticulate bag made of jute strings, which is hanging from the wall or the ceiling. Locally known as shika. It is used as a mini-storage of different things. Many villagers use it as an alternative of chest-of-drawer. 
door. Sometimes, local union parishad member and chairman arranged special guarding by the village-police under their control. To remain safe from snakebite, they spread out leaves of Neem around them. To save the children and infants from missing, the elder members compassionated them at daytime. Beyond all these preventive measures, a few incidents happened at that period of instability.

\subsection{IMMEDIATE SHELTER AFTER DISPLACEMENT}

Shelter is one of the important basic needs at the time of displacement. As there was no government or nongovernmental steps to provide shelter to the displaced households, displacees themselves were eager to search their shelter to shift family members and other household materials. But at the time of displacement, it was not so easy to get a suitable land or house or place to resettle. It was found that their first choice was house or land of relatives or neighbors who were out of erosion risk. It was one kind of competition to get it. Because, every families were on the track to get first welcome address by others. In some cases, river bank erosion displacees made innovative use of kinship ${ }^{10}$ and other ideologies legitimating reciprocity and mutual aid to re-establish themselves rent-free on the land of others. However, it did not show always a well-established way of living as entitlements and poverty tended to inter-household cooperative conflict and mutual aid among extremely poor people.

It was evident that, most of the displacees were taken shelter to their relative or neighbor's house just after displacement. The cause to choose this option was identified as safer place than others were. It was not needed to pay for stay and got help to collect food for family members. Though many of them could not stay long time, but believers considered it as a grace of almighty to make them sympathetic to them.

\subsection{FREQUENCY OF DISPLACEMENT}

There are so many causes for displacement from one place to another. Sometimes, people move willingly and sometimes it is caused by force. This involuntary or forced displacement may be categorized in three major ${ }^{11}$ groups: political displacement, environmental displacement and development-project induced displacement. Forced migrant, inoduced by environmental change is termed as 'environmental refugee'. In every case of displacement, an extreme form of marginalization of individuals and groups takes place ${ }^{12}$. In this study, respondent displacees experienced several times displacement from their living place. Before settling in the study area, they built their house within the vicinity of riverbank erosion ${ }^{13}$. The reason behind was, they thought riverbank would not be eroded more and they would get back their land. However, every time, their dreams washed out with the bank erosion and they compelled to shift houses to another place. Respondents told that none of them was ready to leave their beloved place of birth. Some of them still hope to go back to their original land if land accretion happens. However, they agreed that it was not possible for them to go back and adapt again with new formation of land. As a last option, they settled in this place. From the study, it was found that a good number of respondents lived in the char areas. Chars are more vulnerable to erosion and every year the inhabitants loss their land. This multiple shifting, took them quickly to under the poverty line. Their living status

${ }^{10}$ Doreen Marie Indra and Norman Buchignani, "Rural Landlessness, extended entitlements and inter-household relations in South Asia: A Bangladesh Case", Journal of Peasant Studies, Vol. 24, Issue 3, April, 1997, pp. 25-64. 24.07.2008.

http://www.informaworld.com/smpp/content content=a790270448 db=all order=page dated:

${ }^{11}$ Heming and Rees, op.cit., pp. 439-462.

12 Ibid.

13 Professor Abdul Baki (ed.), Duryogbarta, Disaster Research Training and Management Center, Dept. of Geology and Environment, DU, Vol. 13, 2006, p. 6. 
and livelihood pattern changed simultaneously. The rainy season, followed by flood is considered most vulnerable period for riverbank erosion- which nature is not same. Sometimes the rate of erosion increases, making a mass shifting of bank-inhabitants and aggravates maximum land.

The maximum displacement found 12 times of displacement, which was the highest in number among the respondents. Abrar and $\mathrm{Azad}^{14}$ found 19 times of displacement in Lalmonirhat from their study on the same. We may also identify them as a population of 'living with hazard'. They had achieved this implanted force from their community. Displacees lived in a society of strong ties, where collective force offered them some sorts of dependency. FDG members expressed this attitude as 'die-to-die' principle. 'We are born here and want to die also; we can not live except this loving place'.

That was the reason for shifting homestead with the encroachment of bankline. And, at the last time, community members left erosion prone vicinity to safer places. At present, they were living in different places of the country. In FDG, with other questions, they were asked also about the reasons behind living with the threat of erosion. The answer came from different corners of thought, but they believed that they would not be migrated. They believed that once upon a time the erosion would stop and they could get back their land.

\subsection{PROBLEMS FOR SHIFTING FAMILY MEMBERS}

At the time of displacement, a horrible situation arose over the erosion-affected area. Every household of that locality tried to take all the household goods and other movable assets to their new shelter. In that situation, elder members, especially the women took care of children, not to leave away. Respondents compared that situation with the wartime restlessness. They told that during wartime, when heavy bombardment happened, enemy soldiers were coming nearer; the residents had to leave within short time to save life. A very small amount of assets they could take with them. During riverbank erosion, almost the same situation arose. They got a very short time to leave. Within that time, they had to shift or sell all the household goods as well as other movable things.

\subsection{HELP RECEIVED BY THE DISPLACEES FOR SHIFTING}

In this situation, they sought and needed help from others. However, it was not possible for all to help others. Because, all of them were busy with same circumstances. However, it was found that, though they were affected by same natural events and in a same vulnerable condition, they came with helping hands as much as possible. According to them, no other group could understand or could give prompt response other than neighbors. They shared their labor force and worked physically also for other households to shift household goods and family members. They responded quickly and shared all other facilities in that crucial time. That was because, from so many years, they were living side by side, shared their joy and sorrow and asserted security for each other. Relatives were the next group to respond immediately on call of the affected members. Relatives of most of the respondents of Ranihati lived in distant places. Therefore, they took more time to respond. It took time to reach help seeking message. Distant relatives had no knowledge on what kind of support they could provide. At the time of migration, displacees felt unavailability of transport and labor force to shift household goods and family members easily and within short time. Riverbank erosion caused a displacement of large population, who lived in same locality. They had own lifestyle and strong social ties. They had another identity on behalf of their society, which is known as samaj or gosthi. It is a predominant social heritage mainly in rural areas of Bangladesh. Members of a samaj or gosthi are more coherent among themselves, than others living in the same locality. A samaj is formed by one or more than one gosthi, where other members may be included sharing the same beliefs or values. A gosthi is identical by its clan. Almost all the members of samaj or gosthi were affected

\footnotetext{
${ }^{14}$ Abrar and Azad, op.cit., p. 32.
} 
by riverbank erosion, when it took place. At the time of riverbank accretion, samaj or gosthi became mainly inactive as all were engaged in own purpose. So, help from samaj members was not so much expected. Beyond that, members- who were not within the erosion vicinity came to facilitate shifting activities. Victims found no support from government or non-governmental organizations.

\subsection{OLDER MEMBERS, WOMEN AND CHILDREN}

These three groups were found more vulnerable to natural disaster as well as riverbank erosion displacement. Multistage troubles arose in the process of transferring these members. Sometimes they suffered from various types' of hardship or created problems to others.

\subsection{PROBLEMS RELATED TO OLDER MEMBERS}

At the time of leaving home for a new place, an emotional situation took place. All the family members were crying for their unfortunate displacement. Older people were widely accepted as being a vulnerable or potentially vulnerable group ${ }^{15}$. Older members created more complex situation for the young, who were engaged in shifting process. They had no time to waste for resettling family members. A large number of respondents replied that their older members were not willing to go another place leaving their forefathers homestead land. But lack of public awareness and information about older people's contributions, circumstances, issues or needs created negative images of aged members. Other family members were about to forget older peoples' affliction to family in their early age. Older members were so emotional that they wanted to die than to leave. They had spent their childhood in that place. Mementos were touching in every corners of their house. Most of the respondents realized that they had shown anger with their older family members in that situation. Interestingly, they did not feel guilty for misbehaving with their older members. Shifting of older members was another important problem faced by the displacees. Elders, who were incapable to walk or too weak to walk or sometimes unable to climb into a truck or van or on a countryboats, they were taken up on the lap. In that vulnerable situation, they needed special care and attention from other members. On the transport, they occupied more space to lie-down. It was embarrassing for them, when they shared a transport with others or owned by others. Sometimes, respondents had to manage a separate transport for them. Problems concerned to elders did not end by shifting but in the new place, they found more troubles with the environment

\subsection{PROBLEMS RELATED TO WOMEN AND GIRLS}

Women were one of the severe victims of riverbank erosion, which tended them to comparatively a vulnerable group $^{16}$. Women of the respondent households had reported ${ }^{17}$ their helplessness and vulnerability due to displacement induced by riverbank erosion. On the other hand, their male counterparts had expressed variably different attitude to few activities of female members on the eve of shifting. Those comments and observations are stated below:

a) The general comment of women on male members' activities and attitude was that they were kept in the dark about things going on. They were eager to know about the rate of erosion, recent distance of river from

15 "Older people in disasters and humanitarian crises: Guidelines for best practice", HelpAge International, London: NA, pp. 1-20.

16 Sharif A. Kafi, Disaster and Destitute Women (Dhaka: Bangladesh Development Partnership Centre, 1992), p. 73.

17 Their opinions on this issue were collected during Focus Group Discussion meetings in the two study areas. A cross section (male and female) FDG was also arranged with the respondents and female members. 
their place of living and selecting new place to resettle. But there was no direct information system to women to know about this. They were fully dependent on male members.

b) At the time of disaster, pregnant women felt in a critical condition and they felt helpless. They could not move freely due to their physical inability. Other members had to take special care for them, but in that terrible situation, members could do a little for them. If they were needed to take to hospital, it was almost impossible to do so due to unavailability of transport and hazardous communication. Only traditional medicine and nursing facility could be provided for them.

c) Male members wanted to make safe shifting for their family. In that respect, they arranged transport and preparation. Household heads expected to transfer household materials after sending family members. But most of the women desired to be present at the time of packing household goods, so that they could reopen those packs to get essential materials easily. Male members forced them to leave immediately with other members.

d) Women and girls were found more exposed to insecurity, e, i; sexual and domestic violence in disaster contexts $^{18}$. They became a vulnerable group in all respect. Latha has identified several reasons for increased risk of sexual and domestic violence on women and children, in his study on aftermath of Orissa cyclone and Gujrat earthquake. Women seeking shelter during cyclones had been exposed to sexual harassment and assault. Concerns were raised that children misidentified as cyclone 'orphans' were trafficked into sex work. Kafi's ${ }^{19}$ work also supported this findings that girls and women affected by cyclones and floods followed by riverbank erosion, lack of protection from male relatives for widows and other sole women was cited as one of the factors increasing the rate and fear of sexual assault. Girls in families forced by the losses of drought or cyclone to sell off dowry possessions may well be forced into early marriage and child labor increases when hard-hit families must send all members of the household out to work. Families found 'forced-marriage' of their girls in early ages due to lack of security and providing of food.

e) Natural disaster induced displacement took displacees to the periphery of livelihood facilities. It was mentioned earlier that womenfolk of the society suffered more than the male from many purposes. More than 50 percent respondent families of the study areas did not get latrine facilities at their shelter for the first time. It got revealed that those female members could respond to their natural calls only at the very early in the morning or after evening. Living without latrine facility, affected directly to the women, whereas, male members might not accept it as a severe problem. But they were concerned about that problem and managed latrine facility as soon as possible.

f) It was another duty lies on the female members to look after children as well as older members. Male members argued that they had to work outside to earn money for household expenditure and female members were traditionally accountable to look after other members.

\subsection{IMPACT ON PHYSICAL AND MENTAL HEALTH}

It is invariably true that everyone will experience physical or emotional and psychological distress during or in the immediate aftermath ${ }^{20}$ of a disaster or other large-scale traumatic event. Acts of terrorism, natural disasters and other large-scale traumatic events typically result in tremendous loss of life, physical injuries and property damage. Survivors of such tragedies invariably experience significant physical, emotional and psychological distress in the immediate days and weeks that follow. Just after the disaster, respondents reported symptoms ranging from

${ }^{18}$ Prof Dr Krishnadas Mazumder Latha, "Role of Women in Disaster Preparedness", www. authorsDen.com. Dated: 28.06.2008.

19 Ibid.

${ }^{20}$ Matt J. Gray, "Acute Psychological Impact of Disaster and Large-scale Trauma: Limitations of Traditional Interventions and Future Practice Recommendations", Prehospital and Disaster Medicine, Vol. 19, No. 1 (March, 2004), pp. 64-72. 
physical injury, intense fear, anxiety and despair to shock and disbelief ${ }^{21}$, which are compounded by legitimate concerns about safety, shelter and significant financial consequences of the event. Every disaster left few signs over the affected locality.

NIRAPAD ${ }^{22}$ had found out five types impacts of disaster on the affected population as well as over the affected locality. From the figure 2.6, it was seen that respondents of both the study areas had suffered from physical trauma as well as psychological distress due to sudden dislocation and belief of being a permanent displacement from their homestead.

These two types of trauma were discussed below. Respondents and other family members got hurt in the process of shifting. Physical accidents are as follows:

a) Injury: Thirty six percent respondents were injured at the time of shifting of their household goods and family members. Physical injury covers, bleeding or loss or damage of a limb. It was quite natural and unavoidable to be injured in any form of the hazardous shifting process. Others experienced swelling or negligible hurts.

b) Disability: Bone crack due to accident at the time of shifting was found in the 01 percent households of both the study areas.

c) Death: Death due to riverbank erosion was not common like tornado, cyclone, earthquake or other natural disasters.

Every natural disaster left few psychological events for the affected population. For most of them, the adage "time heals all wounds" ${ }^{23}$ was an apt characterization of post-traumatic adjustment. However, after displacement from their homestead, they bore the psychological distress than did non-displacees ${ }^{24}$ though it was expected that they would show maximum resiliency. A thorough survey was done on the respondents of two study areas to find out the psychological impact of displacement. Diversified expressions were observed over them. These are mentioned below briefly:

a) Fear: Many of them feared that the river might grab their present homestead on day. They did not forget the fearful events-when they lived with threat of erosion.

b) Flashbacks: This type of emotional shock made people more vulnerable to be sick. They wanted to look forward but could not build new idea. All the time they thought about their past life, which they believed as a golden time. They remembered their childhood, joyful events, family-life etc. Flashbacks made them emotional and consequently the became psychologically sick.

c) Feeling of pain: Most of the displacees felt mental pain, when they thought about their fate and present situation. Though it was reported as being impossible to describe in words, it was characterized by very painful emotions.

d) Feel helpless: Displacees felt very helpless in the present place of living. In their earlier living area, they had a very strong association; neighbors were helpful to one another in every situation, especially in the emergency time. They had also a mutual understanding of their needs. But in the new settlement area, displacees felt themselves helpless in every situation, as they could not express their needs to the local people.

e) Loneliness: This was another symptom of distressed population. Losing homestead, family members, friends and neighbors they became psychologically weak, and could not make relation with new neighbors.

${ }^{21}$ Ibid.

${ }^{22}$ Md. Rezaul Karim, Post Disaster Psychological Care Manual (Dhaka: NIRAPAD, 2005), p.

9.

23 Ibid.

${ }^{24} \mathrm{http}$ : //pdm.medicine.wisc.edu/Hutton.htm dated: 30.06.2008 
Due to continuous emotional pressure, they became introvert and as a consequence of these matters, they preferred to stay alone and thought about their losses.

f) Disappointment: Disaster victims always looks disappointed due to various reasons. And riverbank erosion displacees were victimized at the maximum that river can do. They looked just like a boat in a sea without sail. They found no light of hope to bear the needs. It was found that due to this displacement, total workhour of the displacees had reduced remarkably by 20-30 percent in both the areas, which varied from male to female also.

g) Low self-esteem: As a disappointed and hopeless man, they lost self-esteem to do something for the betterment of the family members. A number of respondents were found, who did not do anything. Actually they had lost their inner energy and power to do something. In this connection, social workers had more space to gear up these people to start normal life.

h) Sleep disturbance: Respondents reported on their changes in duration of sleep before and after displacement. It was found from their report that they were suffering from sleep disturbance due to migration in a new place and displacement from their original homestead. This may be clarified from the following table.

i) Crying: It was observed from FDGs that most of the displaced persons, especially the women and children cried for their present miserable condition. They could not forget their earlier happiness and way of living. 'Loss of land, loss of everything' - this thinking made them emotional to cry out.

j) Feeling guilty: Sometimes failure to manage situation professionally brought guilty perception to the head of the institution. The riverbank erosion displacees faced a crucial problem during and after displacement in connection with disposing or shifting household goods and family members. Some of them expressed their concern over their land and other on movable assets, which they could sell out or bring with them. Some of them felt guilty to compel family members to participate in the process of shifting who had been injured and disabled.

k) Addiction: It was observed that some of the household members became addicted to be forgetful of their personal and family depression. They were interviewed and agreed that addiction was not the solution but they had nothing to do to overcome sadness.

l) Suicidal tendency: Disaster affected and psychologically distressed people may commit suicide any time after disaster. There are two final stages of psychological distresses, one is schizophrenia and the other is suicide. But it does not always happen to every affected person. In the two study areas, no incidence of suicide was found. Displacees' family ties and sharing family responsibilities by other members might have shown them the light of hope to start from the beginning.

m) Relationship problems ${ }^{25}$ : Relation with the local people sometimes might cause psychological distress to the displacees. The researchers came to know that though most of the local people accepted them cordially but some of them expressed negligence and criticized their sufferings as it was a punishment from Allah for their unbound sins. Sometimes they quote the Qur'anic verses and try to relate with that. Most of the local people identified displacees collectively as 'refugee'. In this context, displacees suffered from relationship problem with local people.

\section{12 PRESENT POLICY AND INSTITUTIONAL SETUP}

25 Frndcine Shapiro, "Eye Movement Desensitization: A New Treatment for Post-traumatic Stress", Disorder. Mental Research Institute, Inc., Palo Alto, California, Vol. 10, No. 3 (1989), pp. 111217. 
Due to the geographical location, the country frequently suffers from devastating natural hazards of which, floods, cyclones, tornadoes, riverbank erosion, drought and earthquakes are the most disastrous to mention. Flood, cyclone, tornado and drought are seasonal disasters in Bangladesh. Earthquakes happen rarely in this country. But only the riverbank erosion is recurrent and it happens throughout the year.

Riverbank erosion is a unique type of environmental disaster due to its destructive nature. In other disasters, resources may loss or people may displace for a short period of time but land exists. On the other hand, land, the primary component of civilization, is washed out, displacement occurs forever. So, no other disaster is as disastrous as riverbank erosion. Unfortunately, it was not considered a specific disaster in Bangladesh before 1993, rather thought to be a consequence of flood. But flood is not turns always a disaster. After continuous campaign and demand from concerned agencies and stockholders, in 1993, government of Bangladesh declared riverbank erosion as a disaster. Though riverbank erosion is a unique type of disaster but it is amalgamated with other disasters and affected people are entertained on the basis of the existing policies and programs of disaster management.

Ministry of Water Resources (MWR) and Ministry of Food and Disaster Management (MFDM) are two key ministries to work in this area. MWR is responsible for riverbank protection and management and MFDM has responsibility for coordinating the government disaster management efforts with two line agencies as the Directorate of Relief and Rehabilitation (DRR) and the Disaster Management Bureau (DMB).

The government of Bangladesh has promulgated The National Water Policy in 1999 providing policy direction for water sector. Planning and Management of Water Resources under the policy (article- 4.2 q) provides directive to 'undertake survey and investigation of the problem of riverbank erosion and develop and implement master plans for river training and erosion control works for preservation of scarce land and prevention of landlessness and pauperisation.' MWR works individually to protect and manage riverbank from erosion without coordinating MFDM.

The National Policy on Disaster Management has emphasized a group of broad based strategies, i.e. risk management, community involvement and non-structural mitigation measures. In Bangladesh there are three bodies for multi-sectoral coordination and collaboration at the national level ${ }^{26}$. a) The National Disaster Management Council (NDMC) is headed by the Prime Minister, b) Inter Ministerial Disaster Management Coordination Committee (IMDMCC), headed by the cabinet Minister in charge of the Ministry of Food and Disaster Management (MFDM) and c) National Disaster Management Advisory Committee (NDMAC) with memberships from both the public and private sectors. There are committees also in district, upazila and union level followed by the directives of national committees.

The Ministry of Food and Disaster Management is responsible for building awareness in pre-disaster phase and distributing relief goods in post-disaster phase as well as rehabilitations in some extend. Certain sections of the displacees are accommodated in allocation of Khas land, Adarshaya Gram and Abashon projects. NGOs like CARE-Bangladesh, OXFAM, BDPC and RDRS are working with displacees in certain areas of Bangladesh.

\subsection{DISCUSSION ON THE POLICIES AND PROGRAMS}

${ }^{26}$ National Report and Information on Disaster Reduction for the World conference on Disaster Reduction, Ministry of Food and Disaster Management, Government of Bangladesh. KobeHyogo, Japan, January 18-22, 2005. 
It is common in Bangladesh that the victims of riverbank erosion do not receive same response from the concerned authorities as received by the victims of flood, tornado and cyclone- who have secured important places in the list of disasters. Because of its slow process and scattered incidences, displacees of riverbank erosion fail to draw attention successfully of the responsible authorities. Riverbank erosion and displacees do not obtain also such media coverage as victims of other disasters get. As a result, almost a silent catastrophe is going on throughout the year to that unfortunate group of people. But there is no specific policy or program for the riverbank erosion displacees either in government or in non-government sectors. Riverbank erosion victims are treated in same manner by the government as victims of other disasters. Government has issued general principles for distribution of relief goods to the victims of disasters, which leaves unequal opportunities for the displacees due to few conditions for getting relief goods. In May 2007, four important government circulars have issued by the Ministry of Food and Disaster Management directing guidelines for distribution of $\mathrm{Cl}$ Sheets, General Relief (cash), allotment (cash) for house building, and General Relief (Food) among the victims of cyclone/fire/flood/riverbank erosion/tidal wave/earthquake.

Riverbank erosion displacees do not get first two types of assistances because of the required qualifications. For getting $\mathrm{Cl}$ Sheets, victims have to have their own land. But 'displacees became displacees' after losing their land due to riverbank erosion. So, they fail to get $\mathrm{Cl}$ Sheets that is essential for building a temporary shelter. They do not get general relief (cash) also. If a person dies due to disaster then his family may get assistance as cash. Fortunately, death is rare in case of riverbank erosion victims. Twenty KGs of rice is distributed to each family only for once as general relief, with which a five-member family can go maximum ten days. Three thousand Taka is given to each family to repair their damage houses.

Problem also lies in selecting victim families. There are temporary shelters build by the government at cyclone prone areas, where people take shelter during cyclone-surge. Authorities can easily get reach to them. They also can reach to those who do not come to the shelter, because they live in their own land. It is also the same for the flood affected people. But there is no temporary shelter for riverbank erosion victims or no early warning system or no early evacuation process to evacuate the inhabitants of erosion prone areas. As a result, after losing homestead, displacees leave the area on their own initiatives to distant safer places as there is no chance for early alluvial of their diluviated land. Field level experience shows that most of them move to different administrative area. So, the officials of their original area cannot assist them and the officials of resettled area have limited scope to help them as they are not the victims of that administrative area. The consequence is that, these environmental refugees become more vulnerable in every sense and compel to live under the extreme poverty line.

It is found that victims of sudden and highly-publicized disasters like the Asian tsunami, Bay of Bengal cyclones (Sidr, Bizli, Aila etc.) or the US Gulf Coast hurricanes are benefited from the mobilization of private and public sector generosity and humanitarian relief. On the other hand, millions of victims of disasters like coastal/riverbank erosion or sea level rising around the world are uprooted by gradual environmental changes, receive comparatively little support to cope and adapt and are not recognized as refugees with the benefits that grants.

It is said that 50 million people worldwide will be displaced by 2010 due to different environmental disasters as scholars are predicting. Developed countries has important role in this connection by providing financial assistance and logistic support. Increasing number of internal displaced population is not only a problem for the affected country but it may also create extra-pressure through 'inevitable migration' to the developed countries. 
Therefore, some changes are needed in existing policies and initiatives of institutions to work for the victims of riverbank erosion. It is needed to consider riverbank erosion as a unique environmental disaster which not only makes people landless and homeless but it also changes the geographical map (by encroaching riverbank) of the land scarce country and increases the number of internal displaced population who finds no way but to live as slum dwellers.

\subsection{RECOMMENDATIONS}

On the basis of the above discussion, the following recommendations are made to reduce the vulnerability and improve the stability of the riverbank erosion induced displacees. The National Disaster Management Council (NDMC) should enact the Comprehensive Riverbank Erosion Management Policy:

1. To ensure the rights and protection of the displacees;

2. Formation of 'Coordination Council' to coordinate bank-protection works and displacees' livelihood development programs.

These programs should include the following phases of erosion risk management at the national as well as local level:

\section{Phase 1 - Pre-displacement Period}

1. Identifying, assessing and monitoring of the potential hazards, risks and vulnerabilities.

2. Organization of effective early warning and information management systems. This guarantees timely and effective dissemination of early warning information to the community level.

3. Building storage systems at district levels in order to effectively dispatch material resources for relief and rehabilitation.

4. Identifying land/khas land to nearby safer zones to improve the management capacity of authority.

5. Regional Disaster Management Center of South Asia for multilateral cooperation.

\section{Phase 2- Emergency Response}

1. Conducting rescue, evacuation and recovery operations as necessary.

2. Determining temporary shelter and facilitate with transport may help the displacees to come to the shelter area.

3. Activating evacuation points/areas and distributing relief and medical supplies to disaster victims.

4. Undertaking rehabilitation activities.

5. Developing recovery plans based on community needs and priorities.

Phase 3- Post Displacement Phase

1. Providing "developmental relief" and recovery services as necessary.

2. Allotment of Khas land and providing accommodation in Adarshya Gram and Abashon projects.

3. Enacting Banking policy to provide loan without interest and write off agricultural loan to the victims.

4. Insurance schemes at soft premiums.

5. Ensuring boundary conditions (river depth, flow velocities, water levels) for different design options (spurs, revetments) based on specific characteristics of major rivers.

6. Introducing two- and three-layer bank protection systems.

\section{CONCLUSION}

Besides different bank protection works, riverbank erosion remains as a continuous threat to the riparian inhabitants and the land-scarce country. Every year, a large number of its population is displaced due to 
riverbank erosion. They loss their land and migrate to another place to make new settlement. These environmental refugees become vulnerable as a whole in every sense. Before deteriorating situation to beyond control, it is high time to take necessary actions to stop forceful displacement and livelihood management of the victims.

\section{BIBLIOGRAPHY}

Abrar, Chowdhury R and Azad, S Nurullah, Coping with Displacement, Dhaka: RDRS Bangladesh, 2004.

Disaster Report: 1997, Bangladesh Disaster Preparedness Forum, Dhaka, Bangladesh.

-2000, Bangladesh Disaster Preparedness Forum, Dhaka, Bangladesh.

Doreen Marie Indra and Norman Buchignani, "Rural Landlessness, extended entitlements and interhousehold relations in South Asia: A Bangladesh Case", Journal of Peasant Studies, Vol. 24, Issue 3, April, 1997, pp. 25-64.

Elahi, K. Maudood et. al., (eds.). Riverbank Erosion, Flood and Population Displacement in Bangladesh. Dhaka:Riverbank Erosion Impact Study, 1991.

Frndcine Shapiro, "Eye Movement Desensitization: A New Treatment for Post-traumatic Stress", Disorder. Mental Research Institute, Inc., Palo Alto, California, Vol. 10, No. 3 (1989), pp. 111-217.

Heming, Li and Rees, Philip, "Population Displacement in the Three Gorges Reservoir Area of the Yangtze River, Central China: Relocation Policies and Migrant Views", International Journal of Population Geography, Vol. 6, 2000.

Islam, M. Zulfiquar Ali. "Social Resilience of the riverbank Erosion Displacees in Bangladesh". Ecology and Human Well-Being. Eds. By Pushpam Kumar and B. Sudhakara Reddy. New Delhi: Sage Publications India Pvt Ltd. 2007.

Kafi, Sharif A., What People can do to Reduce the Disastrous Effects of River Erosion, Dhaka: PactBangladesh/PRIP, 1993.

Matt J. Gray, "Acute Psychological Impact of Disaster and Large-scale Trauma: Limitations of Traditional Interventions and Future Practice Recommendations", Prehospital and Disaster Medicine, Vol. 19, No. 1 (March, 2004), pp. 64-72.

Md. Rezaul Karim, Post Disaster Psychological Care Manual (Dhaka: NIRAPAD, 2005), p. 9.

Ministry of Food and Disaster Management, Government of Bangladesh, National Report and Information on Disaster Reduction for the World conference on Disaster Reduction,. Kobe-Hyogo, Japan.

National Report and Information on Disaster Reduction for the World conference on Disaster Reduction, Ministry of Food and Disaster Management, Government of Bangladesh. Kobe-Hyogo, Japan, January 18-22, 2005.

Nizamuddin, k., ed., Disaster in Bangladesh, Dhaka: Disaster Research Training and Management Centre, undated.

"Older people in disasters and humanitarian crises: Guidelines for best practice", HelpAge International, London: NA, pp. 1-20.

Professor Abdul Baki (ed.), Duryogbarta, Disaster Research Training and Management Center, Dept. of Geology and Environment, DU, Vol. 13, 2006, p. 6.

Prof Dr Krishnadas Mazumder Latha, "Role of Women in Disaster Preparedness", www. authorsDen.com. Dated: 28.06.2008.

Sharif A. Kafi, Disaster and Destitute Women (Dhaka: Bangladesh Development Partnership Centre, 1992), p. 73. 
The daily Jugantor, 21.06.2008.

www.coastbd.org

environment.about.com

www.climate.org

http://www.informaworld.com/smpp/content content=a790270448 db=all order=page dated: 24.07.2008.

http: //pdm.medicine.wisc.edu/Hutton.htm dated: 30.06.2008 